University of Nebraska - Lincoln

DigitalCommons@University of Nebraska - Lincoln

Faculty Publications from the Harold W. Manter Laboratory of Parasitology

1996

Emended Description of Mazamastrongylus peruvianus

(Nematoda: Trichostrongylidae) with Comments on the

Relationships of the Genera Mazamastrongylus and

Spiculopteragia

Eric P. Hoberg

United States Department of Agriculture, Agricultural Research Service, geocolonizer@gmail.com

Follow this and additional works at: https://digitalcommons.unl.edu/parasitologyfacpubs

Part of the Parasitology Commons

Hoberg, Eric P., "Emended Description of Mazamastrongylus peruvianus (Nematoda: Trichostrongylidae) with Comments on the Relationships of the Genera Mazamastrongylus and Spiculopteragia" (1996). Faculty Publications from the Harold W. Manter Laboratory of Parasitology. 729.

https://digitalcommons.unl.edu/parasitologyfacpubs/729

This Article is brought to you for free and open access by the Parasitology, Harold W. Manter Laboratory of at DigitalCommons@University of Nebraska - Lincoln. It has been accepted for inclusion in Faculty Publications from the Harold W. Manter Laboratory of Parasitology by an authorized administrator of DigitalCommons@University of Nebraska - Lincoln. 


\title{
EMENDED DESCRIPTION OF MAZAMASTRONGYLUS PERUVIANUS (NEMATODA: TRICHOSTRONGYLIDAE), WITH COMMENTS ON THE RELATIONSHIPS OF THE GENERA MAZAMASTRONGYLUS AND SPICULOPTERAGIA
}

\author{
E. P. Hoberg
}

United States Department of Agriculture, Agricultural Research Service, Biosystematics and National Parasite Collection Unit, BARC East No. 1180, 10300 Baltimore Avenue, Beltsville, Maryland, 20705-2350

\begin{abstract}
Resurrection of Mazamastrongylus as proposed by Jansen (1986) was validated and placement of Mazamastrongylus peruvianus in this genus was confirmed, based on characters of the synlophe, copulatory bursa, and spicules. The cervical synlophe consists of a strongly tapering pattern and prominent "hood ridges" at the level of the excretory pore; there are 40 ridges at the midbody of males. The bursa is of the 2-2-1 type, with rays 2 and 3 parallel and rays 4 and 5 of near equal length and only slightly divergent at the tips. The spoon-shaped dorsal process of the spicules, typical of $M$. peruvianus and other species of Mazamastrongylus is postulated as a synapomorphy for the genus. The genera Mazamastrongylus, Spiculopteragia, and Sarwaria are considered to be independent based on characters of the synlophe, spicules, and copulatory bursa. Host and geographic distributions for species of Mazamastrongylus appear to be consistent with a history of coevolution and colonization and relationships for $M$. peruvianus may parallel the pattern postulated for species of Nematodirus in cervids and camelids in the Neotropics.
\end{abstract}

Specimens of the ostertagiine nematode Mazamastrongylus peruvianus (Guerrero and Chávez, 1967) were originally described as Spiculopteragia (Dorsagia) peruvianus Guerrero and Chávez, 1967 from alpaca (Lama pacos (L.)), vicugna (Vicugna vicugna (Molina)), and guanaco (Lama guanicoe (Muller)) in Peru (Guerrero and Chávez, 1967). Records of this parasite appear to be limited to the original description.

The generic-level allocation for $S$. peruvianus has been problematic. Jansen (1981) and Hinaidy and Prosl (1981) referred S. peruvianus to the genus Spiculopteroides Jansen, 1958. Later, morphological similarities between specimens of this species and those of Mazamastrongylus trinitatis Cameron, 1935 were recognized by Jansen (1986), although detailed comparisons had not been presented in the original description (Guerrero and Chávez, 1967). Thus, when Jansen (1986) resurrected Mazamastrongylus Cameron, 1935, the genera Spiculopteroides, Sarwaria Dróżdż, 1965, and the subgenus Dorsagia Guerrero and Chávez, 1967 were synonomized; 8 species of ostertagiines including $S$. peruvianus were referred to Mazamastrongylus. The genus was defined by the configuration of the ventral and lateral rays of the copulatory bursa and the structure of the accessory bursal membrane (see Jansen, 1986; Dróżdż, 1995).

In contrast, Durette-Desset $(1982,1983,1989)$ had considered Mazamastrongylus to be a synonym of Spiculopteragia Orloff, 1933. However, she referred $S$. peruvianus to Teladorsagia Andreeva and Satubaldin, 1954, based on the synonymy of the subgenus Spiculopteragia (Dorsagia) Guerrero and Chávez, 1967 with the former genus (Durette-Desset, 1989).

Consequently, the species originally designated as $S$. peruvianus has been referred to 4 genera including Spiculopteragia, Mazamastrongylus (=Spiculopteroides), and Teladorsagia. This situation further highlights the continuing confusion over generic-level taxonomy and systematics for the Ostertagiinae Lopez-Neyra, 1947 (see Durette-Desset, 1982, 1983, 1989; Gibbons and Khalil, 1982; Jansen, 1989; Lichtenfels and Hoberg, 1993; Hoberg and Lichtenfels, 1994; Dróżdż, 1995).

Received 20 November 1995; revised 15 February 1996; accepted 15 February 1996.
Placement of S. peruvianus in Mazamastrongylus and validation of the genus as advocated by Jansen (1986) and Dróżdż (1995) are evaluated in the present study. An emended description of the species includes attributes of the bursal rays, genital cone, spicules, esophagus, ovejectors, and female tail, among characters not considered in detail in the original description (see Guerrero and Chávez, 1967). The synlophe is compared among those species, Mazamastrongylus pursglovei (Davidson and Prestwood, 1979), Mazamastrongylus odocoilei (Dikmans, 1931) and M. trinitatis, where the pattern of longitudinal cuticular ridges has been assessed (Lichtenfels et al., 1993). Aspects of host distribution and geographic range for species of $\mathrm{Maza}$ mastrongylus and Spiculopteragia are also considered.

\section{MATERIALS AND METHODS}

Specimens were studied as temporary wholemounts cleared in phenol-alcohol (80 parts melted phenol crystals and 20 parts absolute ethanol) or in glycerine and examined with differential interference contrast light microscopy. Transverse sections of a male specimen were prepared free-hand with a cataract knife and embedded in glycerine jelly; sections of females were not prepared as an insufficient number of specimens was available. Sections were used to study the structure of the synlophe in the cervical zone (including the region of the esophageal-intestinal junction), anterior quarter, midbody, and posterior region. Figures of sections were oriented with dorsal surface toward the top of the plate and shown as if viewed from the anterior. Throughout the manuscript, measurements are presented in micrometers unless specified otherwise and presented as a range with mean \pm 1 SD in parentheses.

The current study focused on the configuration of the synlophe, esophageal valve and genital cone (following Lichtenfels and Pilitt, 1991; Hoberg et al., 1993a). Other meristic and structural characters are included in the emended description (measurements of the ovejectors follow Lichtenfels and Pilitt, 1991). Genital papillae and bursal rays are numbered according to the methodology developed by Chabaud et al. (1970), and the orientation of the synlophe follows concepts presented by Durette-Desset $(1983,1985)$.

Specimens were obtained from the US National Parasite Collection (USNPC) maintained at the Biosystematics and National Parasite Collection Unit, United States Department of Agriculture, Beltsville, Maryland. Material included 13 males (4 permanently mounted; 9 unmounted, preserved in ethanol) and 2 females (unmounted, preserved in ethanol), of $S$. peruvianus Guerrero and Chávez, 1967 from an alpaca (Llama alpaca) collected at Puno, Peru, and deposited as USNPC no. 59236. These specimens evidently represent part of the type series of 


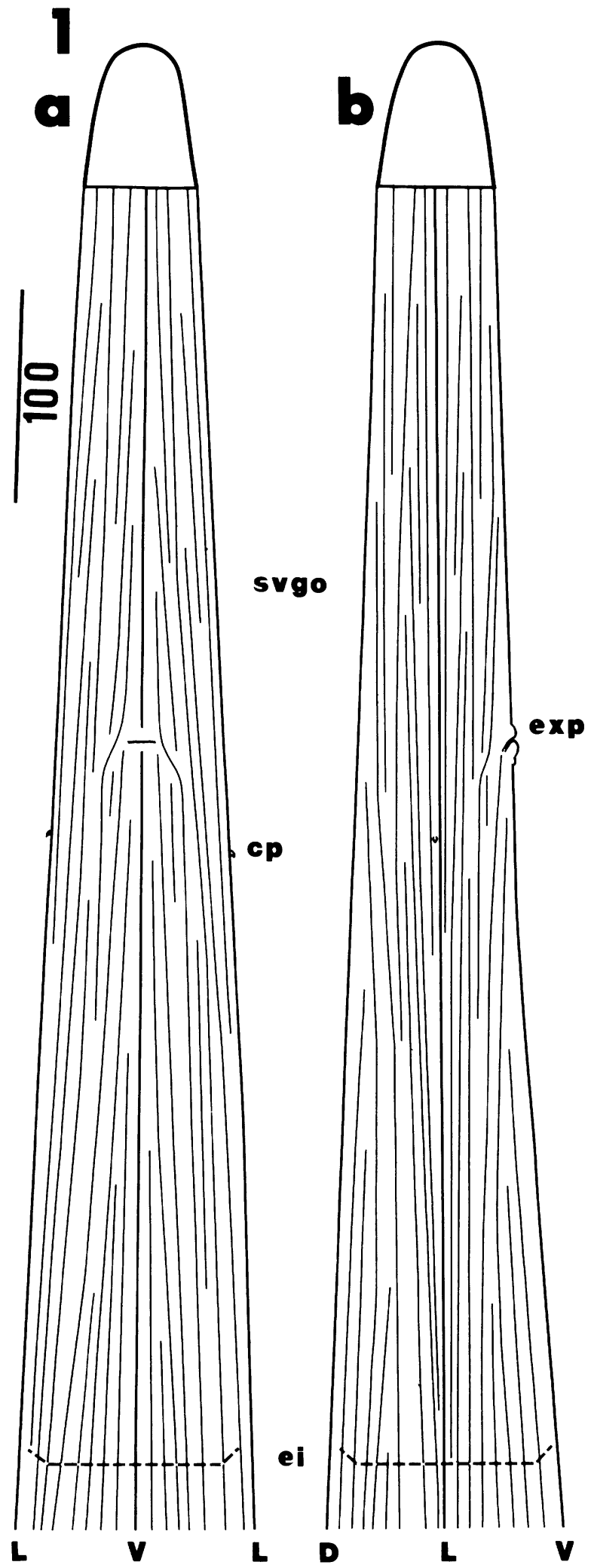

Figure 1. Synlophe in the cervical region of Mazamastrongylus peruvianus (Guerrero and Chávez, 1967) anterior to the esophagealintestinal junction (ei) in a male specimen. Scale bar in micrometers. 1a. Ventral synlophe showing tapering pattern with ridges extending across to the lateral fields, typical hood ridges, and broad liplike excretory pore (exp) and position of the subventral gland orifices (svgo). 1 b. Lateral synlophe showing strongly tapering pattern extending posterior from cervical papillae (cp).
20 males and 10 females on which the original description was based. In the original paper, a holotype and allotype were not apparently designated, nor was it specified where the remaining type specimens were deposited (Guerrero and Chávez, 1967).

Additional specimens for comparative purposes included: (1) USNPC no. 70318, M. pursglovei (Davidson and Prestwood, 1979) in Odocoileus virginianus (Zimmermann) from Louisiana; (2) USNPC no. 70309, $M$. odocoilei (Dikmans, 1931); in O. virginianus from Georgia; and (3) Institute of Parasitology, McGill University, Ste-Anne-de-Bellevue, Quebec, Canada, no. V000751, M. trinitatis Cameron, 1935 in Mazama americana (Erxleben) (originally listed as Mazama simplicicornis by Cameron $(1935,1936)$ ) from Trinidad; specimens designated as paralectotypes by Jansen (1986).

\section{RESULTS}

\section{Characters}

An emended description of M. peruvianus included characters not considered in detail in the original description. Among these are attributes of the synlophe, esophagus, genital cone, spicules, and vulval region (Figs. 1-14). Meristic data are presented in Table I.

\section{Synlophe}

The synlophe of $M$. peruvianus is composed of a largely symmetrical system of discontinuous tapering cuticular ridges that extends from the base of the cephalic expansion (Fig. 1) to near the prebursal papillae in males and posterior to the vulva in females. Ridges are perpendicular to the body wall and lack a well defined gradient (Figs. 2, 3). In the cervical zone (anterior to the base of the esophagus), 16 ridges attain the base of the cephalic expansion. Overall, the synlophe is defined by a tapering pattern in both the ventrodorsal and lateral fields. Ventrally the ridges form a hood adjacent to the protruding and prominent excretory pore (Fig. 1a). Pairs of ridges extend posteriad across the ventral and dorsal fields to terminate on the lateralmost ridges; continuous subventral and subdorsal ridges are lacking. Laterally, a strongly tapering pattern is evident with variable pairs of ridges terminating adjacent to the lateralmost ridge in the cervical zone (Fig. 1b). The synlophe is of even height and the interval between ridges is less laterally than in either the dorsal or ventral fields.

Posterior to the cervical zone, the tapering pattern continues for approximately $33-47 \%$ of the body from the anterior, becoming entirely parallel posteriad, with 5-8 closely spaced ridges in each lateral field; in the subventral and subdorsal fields irregular termination and origin of ridges occurs in the posterior half of the body. There is a poorly defined gradient in size, with ridges in the lateral fields being slightly smaller than those disposed ventrally and dorsally; the interval between ridges is also greater in the ventral and dorsal fields.

The numbers of ridges increase posteriad in males and females. Accurate counts for ridges in females could not be determined; approximately $37-40$ are present in the region of the midbody. In males, there are 28-31 ridges at the level of the minuscule thornlike cervical papillae. Variation in numbers is attributable to differences in the levels of origin and termination for individual ridges in the cervical zone. At the limit of the esophageal-intestinal (EI) junction, there are 34-35 ridges. Posterior to the cervical zone, there are 37-38 ridges at the end of the first quarter, increasing to a maximum of 40 at the midbody 


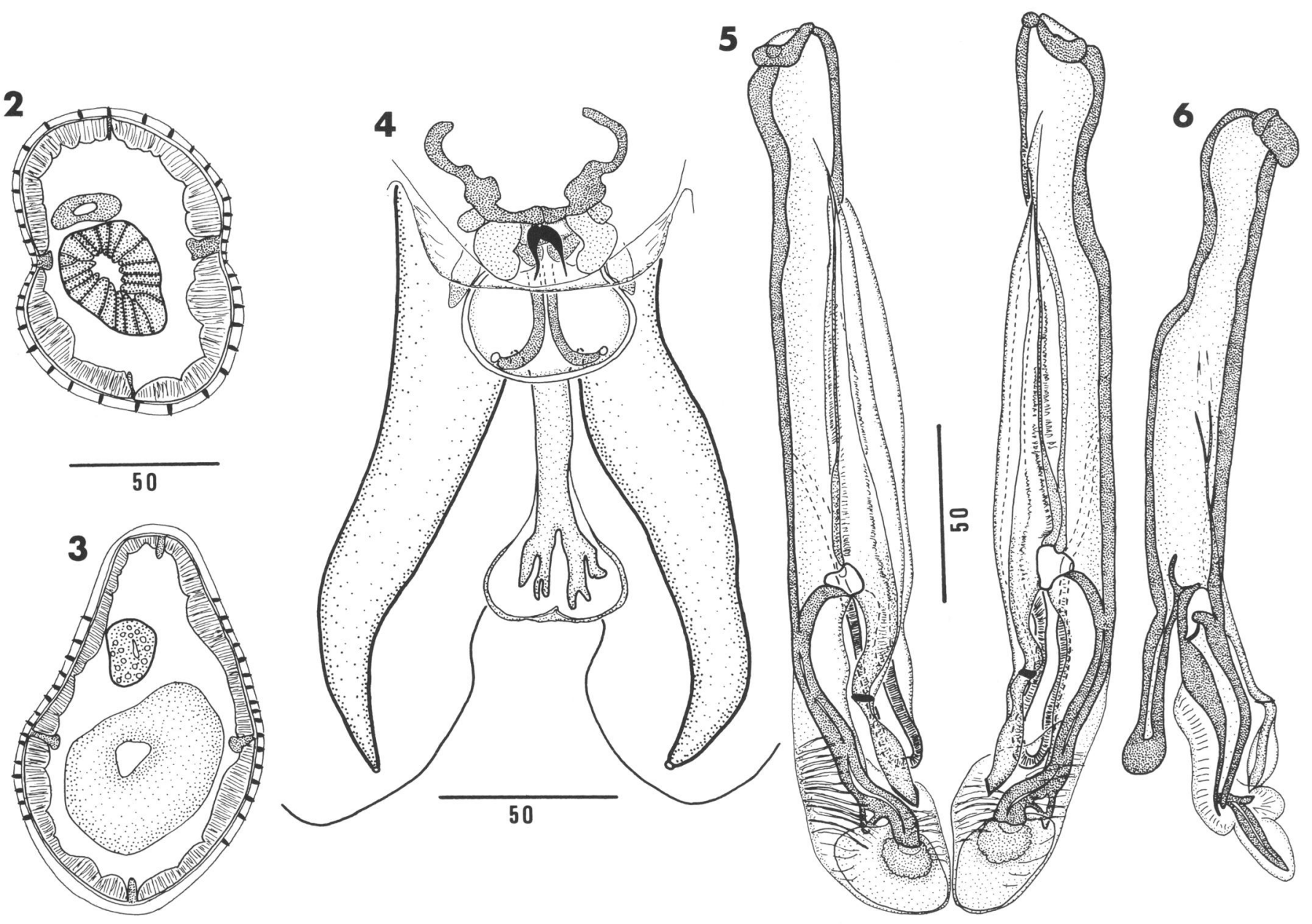

Figures 2-6. Mazamastrongylus peruvianus (Guerrero and Chávez, 1967). Scale bars in micrometers. 2. Transverse section of male specimen near midbody (dorsal to top) showing perpendicular orientation of the synlophe. Note small lateralmost ridges and relatively close spacing of ridges in lateral fields compared to dorsal and ventral fields. 3. Transverse section of male in posterior fourth of body, adjacent to spicules, showing absence of ridges in the dorsal and ventral fields. 4. Region of genital cone in ventral view showing prominent, paired "0" papillae, oval accessory bursal membrane (ABM) with paired " $\mathrm{j}$ "-shaped "7" papillae, lateral protuberances at level of ABM, and rounded dorsal lobe situated ventrally to externodorsal rays. 5. Spicules in ventral view showing trifurcate tips with barb and diffuse triangular foot and membrane on main shaft, ventral process with cuticularized joint and angular tip, and prominent, spoon-shaped dorsal process (based on spicules in situ and dissected). 6. Right spicule in lateral view showing spoon-shaped dorsal process, main shaft with barb and membrane, and ventral process with characteristic joint.

(Fig. 2). Ridges terminate first ventrally up to $78 \%$ of body length and then dorsally at $90 \%$ of body length from the anterior, forming an arcuate gap; by the third quarter, there are 34 ridges in the lateral fields and the synlophe is lacking dorsally and ventrally. Anterior to the spicules, ridges decrease to 32 in the lateral fields (Fig. 3), with these extending to near the level of the prebursal papillae.

\section{Esophagus}

The esophagus is claviform, with the widest region being near the level of the esophageal-intestinal (EI) valve. The orifices of the subventral esophageal glands are usually substantially anterior to both the cervical papillae and the excretory pore (Table I; Fig. 7). The EI valve is relatively long in males and females (81-105 $\mu \mathrm{m}$ ) (Table 1; Fig. 8). A minuscule, triangular, dorsal esophageal tooth is present.

\section{Bursal pattern and genital cone}

The bursal ray formula is 2-2-1 (see Durette-Desset, 1983) with rays 2 and 3 (ventral rays) parallel, with slightly divergent tips, and rays 4 and 5 (antero- and mediolateral) of near equal length with slightly divergent tips (see Guerrero and Chávez, 1967). The genital cone is bluntly rounded with lateral processes occurring at the level of the cloaca (Fig. 4). The ventral or "0" papillae are paired, pointed, and weakly pyriform in shape, contained in a membrane, and located on the ventral aspect of the genital cone. A transversely elongate membrane extends ventrally across the " 0 " papillae and cloaca. The accessory bursal membrane is ovoid, defined by a cuticularized border and positioned transversely on the dorsal aspect of the genital cone, dorsal to the cloaca (Fig. 4). The " 7 " papillae are narrow and parallel proximally, with tips that diverge along the distal margin of the accessory bursal membrane (Fig. 4). Rays 9/10 (dorsal 

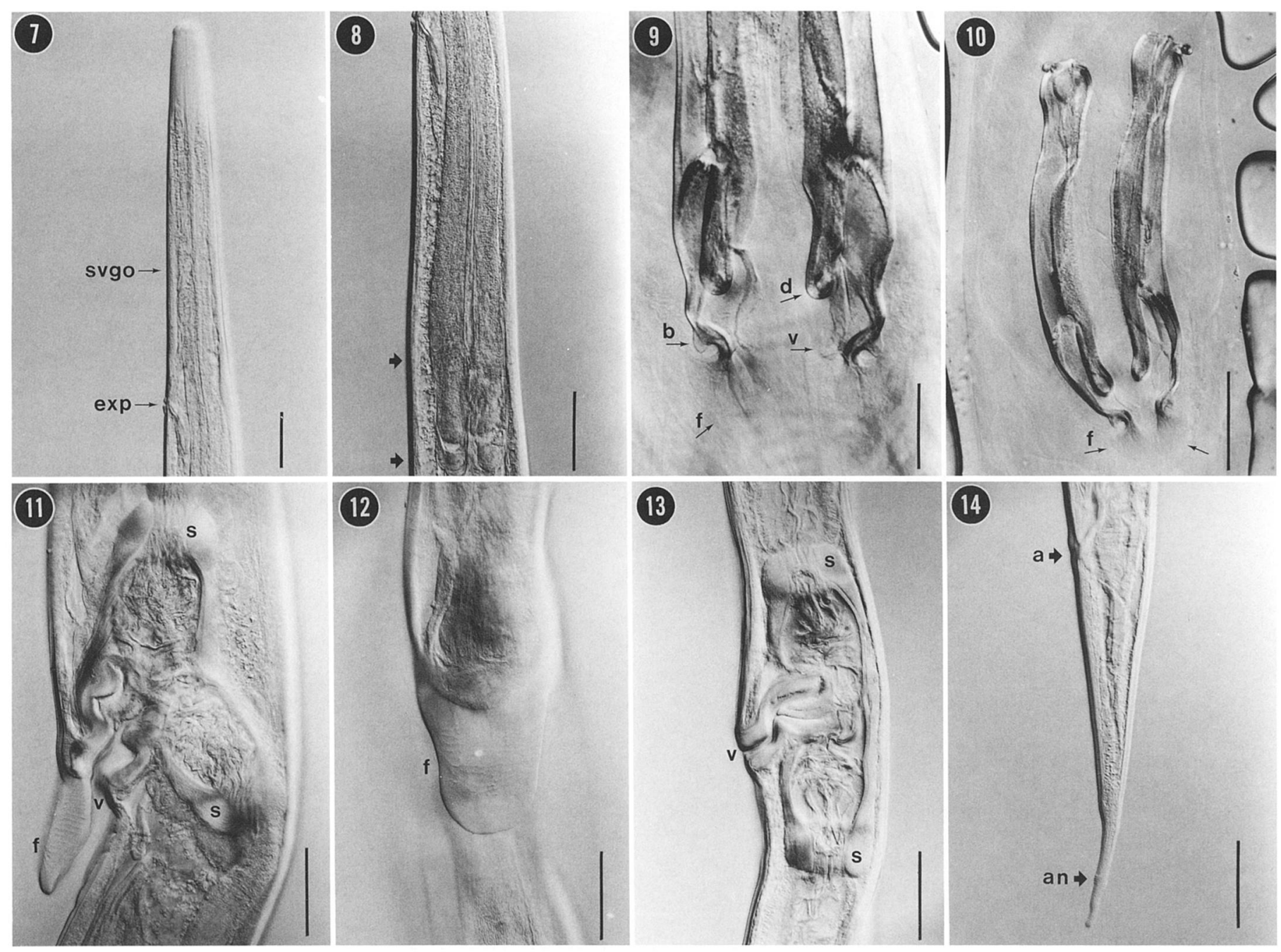

FIGURES 7-14. Mazamastrongylus peruvianus (Guerrero and Chávez, 1967) as observed with interference contrast microscopy. Scales $=50$ $\mu \mathrm{m}$ for Figures 7, 8, and 10-14; for Figure 9, scale $=30 \mu \mathrm{m}$. 7. Cephalic and cervical region showing capsule, position of the subventral gland orifices (svgo), and liplike excretory pore (exp). 8. Esophageal valve (between arrows). 9. Spicule tips in ventral view showing main shaft with barb (b) and triangular foot (f), poorly cuticularized ventral process (v), and spoon-shaped dorsal process (d). 10. Spicules, dorsal view, showing processes and foot (f). 11. Vulval region in female, lateral view showing flap (f), vulva (v), and muscular bulbs of the sphincters (s), excluding the anterior and posterior infundibula. 12. Vulval flap (f) in ventral view. 13. Vulval region and ovejectors, excluding the infundibula, in a specimen lacking a vulval flap, showing position of vulva (v) and muscular bulbs of sphincters (s). 14. Caudal region of female in lateral view, showing relative position of anus (a) and cuticular annulations near tail tip (an).

ray) are contained in a small lobe and positioned ventrally to ray 8 (externodorsal rays), with a bifurcation near $67-72 \%$ of the ray length from the anterior; distally there are three paired lateral processes.

\section{Spicules}

The spicules are relatively complex. Single dorsal and ventral processes of unequal length originate from the respective ala at $60-67 \%$ of the spicule length from the anterior. The dorsal process is relatively long, slender, and spoon-shaped, extending greater than half the length of the main shaft from the trifurcation (Figs. 5, 6, 9, 10); the obscure ventral process is sinuous and weakly cuticularized, with a joint near midlength and an angular cuticularized tip (Figs. 5, 6, 9). The primary shaft of each spicule has a prominent barb directed laterally and slightly dorsally to an obscure triangular foot; the entire tip of the main shaft is encapsulated in a striated membrane (Figs. 5, 6, 9). A gubernaculum is absent.

\section{Females}

Specimens with a synlophe and esophageal structures identical to those found in males were considered to represent $M$. peruvianus. The vulva was located at $81-82 \%$ of body length from the anterior. Modification of the cuticle at the level of the vulva such as inflations were not observed. A flaplike structure at the vulva was well developed in one specimen but absent in the second specimen (Figs. 11-13). The lengths of the infundibula and sphincters did not differ substantially in the anterior 
TABLE I. Meristic and morphological data for males and females of Mazamastrongylus peruvianus (Guerrero and Chávez, 1967); measurements in micrometers with range and mean $\pm 1 \mathrm{SD}$ in parentheses.

\begin{tabular}{|c|c|c|c|}
\hline \multirow{2}{*}{$\begin{array}{l}\text { Characters } \\
\text { Body length }\end{array}$} & \multicolumn{2}{|c|}{ Males $(n=13)$} & \multirow{2}{*}{$\frac{\text { Females }(\mathrm{n}=2)}{7,066-8,785}$} \\
\hline & $(12)^{*} 6,402-8,162$ & $(7,249 \pm 429.40)$ & \\
\hline Cephalic vesicle length & (8) $83-96$ & $(91 \pm 4.83)$ & - \\
\hline Esophagus length & (12) 594-726 & $(676 \pm 41.13)$ & $653-711$ \\
\hline Esophagus as \% of body length & (12) $8.9-10$ & $(9.4 \pm 0.43)$ & $8.1-9.2$ \\
\hline \multicolumn{4}{|l|}{ Esophageal-intestinal valve } \\
\hline Length & $81-105$ & $(91 \pm 6.89)$ & $90-99$ \\
\hline Width & $40-78$ & $(60 \pm 12.20)$ & $53-59$ \\
\hline \multicolumn{4}{|l|}{ Subventral esophageal } \\
\hline Gland orifices† & (12) 239-273 & $(259 \pm 13.83)$ & $239-257$ \\
\hline Excretory pore $†$ & $315-352$ & $(331 \pm 14.00)$ & $322-350$ \\
\hline Cervical papillaet & $326-406$ & $(372 \pm 26.23)$ & 344-394 \\
\hline Spicules length & $195-252$ & $(238 \pm 14.45)$ & - \\
\hline$\%$ Spicule anterior of trifurcation & $60-67$ & $(64 \pm 2.0)$ & - \\
\hline Bursa formula & $2-2-1$ & & - \\
\hline Dorsal ray length & 73-99 & $(84 \pm 8.61)$ & - \\
\hline Vulva position $†$ & & & (2) $5,790-7,135$ \\
\hline$\%$ Body length to vulva & & & $81-82$ \\
\hline Anterior infundibulum length & & & (2) $\quad 180-192$ \\
\hline \multicolumn{4}{|l|}{ Anterior sphincter } \\
\hline and vestibule length & & & (2) $105-124$ \\
\hline Posterior infundibulum length & & & (2) $192-195$ \\
\hline \multicolumn{4}{|l|}{ Posterior sphincter } \\
\hline and vestibule length & & & (2) 101-102 \\
\hline Ovejector length & & & (2) $\quad 594-597$ \\
\hline Tail length & & & (2) $155-229$ \\
\hline
\end{tabular}

* Number of specimens or measurements.

$\dagger$ Measured or determined from the anterior.

and posterior (Fig. 11, 13; Table I). Although based on a limited sample, the tail varied considerably in length (Table I) and usually several prominent annulations were present (Fig. 14).

\section{DISCUSSION}

Morphological and meristic characters of specimens of $M$. peruvianus as observed in the present study were generally consistent with the original description (Table I; Guerrero and Chávez, 1967). However details of the synlophe, esophageal valve, genital cone, and spicules had not been defined. Additionally, in the original description, when placed in Spiculopteragia the differential diagnosis did not consider those species then referred or later transferred to Mazamastrongylus (see Guerrero and Chávez, 1967; Jansen, 1986).

The synlophe in males and females was found to be largely identical, consisting of 34-35 continuous ridges at the level of the EI junction. The numbers of ridges were found to increase posteriad and usually attained a maximum of 40 near the midbody. In the posterior of males arcuate gaps are present in the synlophe in the ventral and dorsal fields adjacent to the prebursal papillae.

The pattern of cuticular ridges in the cervical region is similar to that described for other species of Mazamastrongylus. Characters of the surface cuticle shared with $M$. pursglovei, $M$. odocoilei, and $M$. trinitatis include the ventral complex of hood ridges surrounding the prominent, liplike excretory pore, strongly tapering systems both laterally and dorsally, and absence of definable subdorsal and subventral ridges (Fig. 1) (see Lichtenfels et al., 1993). Ridges extend from the ventral and dorsal fields to terminate near the lateralmost ridges. However, specimens of $M$. peruvianus (Fig. 2) have a greater number of ridges in the midbody region (40) as compared to $M$. pursglovei (2730), $M$. odocoilei (30-32), and $M$. trinitatis (about 30) (Jansen, 1986; Lichtenfels et al., 1993).

The claviform esophagus observed in $M$. peruvianus (Fig. 8) appears typical of those species examined by Lichtenfels et al. (1993). Although the length of the valve overlaps, it appears relatively longer in $M$. peruvianus $(x=91 \mu \mathrm{m})$ compared to $M$. pursglovei $(x=81 \mu \mathrm{m}), M$. odocoilei $(x=76 \mu \mathrm{m})$, and $M$. trinitatis $(x=77 \mu \mathrm{m} ; \mathrm{n}=6)$. Although Cameron (1935) had considered the structure of the esophagus to be unique at the generic level, it does not appear to differ substantially from that among other ostertagiine nematodes (Jansen, 1986).

In females, ornamentation at the level of the vulva was not consistently present in $M$. peruvianus. Although a prominent vulval flap was shown in the original description (Guerrero and Chávez, 1967), a specimen examined in the current study had an unmodified vulva (Figs. 11-13). Among other species of Mazamastrongylus, vulval flaps may be present or absent, typical of variation in this character among ostertagiines (Lancaster and Hong, 1990). Cuticular crests and irregular inflations at the level of the vulva (see Hoberg et al., 1993b), although present in $M$. trinitatis (E. P. Hoberg, unpubl. obs.; 4 of 5 females examined), $M$. odocoilei, and $M$. pursglovei, were not observed in the limited sample of $M$. peruvianus. 
The structure of the bursa was consistent with the original description and is typical of the 2-2-1 type (Guerrero and Chávez, 1967). The genital cone and particularly the structure of the accessory bursal membrane and " 7 " papillae (Fig. 4) is consistent with those described for $M$. trinitatis and other species of the genus (Jansen, 1986; Lichtenfels et al., 1993). The ovoid accessory bursal membrane is only slightly cuticularized and is supported by slender and divergent " 7 " papillae; lateral processes were present at the margin of the cloaca.

The original description of $M$. peruvianus recognized the triangular termination of the main shaft of the spicule tips (Guerrero and Chávez, 1967). However, the adjacent distal structures, particularly the striated membrane and tips of the dorsal and sinuous ventral processes were inadequately described (Figs. 5, $6,9,10)$. The spoon-shaped cuticularized dorsal process and a weakly cuticularized ventral process with a characteristic joint appear typical of the genus (see discussion below).

In agreement with Jansen $(1986,1989)$, characters of the bursa, genital cone, and spicules are consistent with placement of M. peruvianus in Mazamastrongylus. Additionally, the unique tapering pattern and hood ridges appear typical for species of Mazamastrongylus and are highly distinct when compared to cervical synlophes characteristic of Ostertagia and Teladorsagia (Lichtenfels and Pilitt, 1991; Lichtenfels et al., 1993). This refutes placement of $M$. peruvianus in Teladorsagia as advocated by Durette-Desset (1989). The cervical synlophe of Mazamastrongylus is most similar to that among species of Spiculopteragia (E. P. Hoberg, unpubl. obs.). However, Mazamastrongylus is distinct from the latter based on major characters of the bursa and spicules (Jansen, 1986; Dróżdż, 1995).

In Mazamastrongylus, the bursa has parallel and slightly divergent ventral rays (rays 2 and 3) and the antero- and mediolateral rays (4 and 5) are of near equal length with slightly divergent tips (Jansen, 1986). These characters confirm the synonymy of Mazamastrongylus and Spiculopteroides as previously established (see Jansen, 1986; contrary to Gibbons and Khalil, 1982). In contrast, Spiculopteragia is characterized by ventral rays that are not parallel, but converge distally, and a ray 4 that is substantially shorter than ray 5 (Hinaidy and Prosl, 1981; Durette-Desset, 1983; Jansen, 1986). Thus, in agreement with Jansen (1986, 1989), Mazamastrongylus cannot be reduced as a synonym of Spiculopteragia as advocated by Travassos (1937) and Durette-Desset $(1982,1983,1989)$, but a close relationship for these genera is evident (Sarwar, 1957; Dróżdż, 1965, 1967, 1995). Additionally, the structure of the spoon-shaped dorsal process of the spicule may be considered a putative synapomorphy for Mazamastrongylus. Apparently Jansen (1986) did not consider that this character in $M$. trinitatis was other than a species-level attribute. However, among those species transferred first to Spiculopteroides by Hinaidy and Prosl (1981) and later to Mazamastrongylus by Jansen (1986), a characteristic, highly cuticularized and spoon-shaped dorsal process is present. These species include M. trinitatis (type for genus), Mazamastrongylus dagestanica (Altaev, 1953) (according to Dróżdż [1965] and Jansen [1986] $=S$. alcis (Shul'ts, Kadenatsii, Evranova, and Schaldibin, 1952) and S. popovi Ervanova, 1954), M. peruvianus, M. pursglovei, and M. odocoilei. This attribute is evident, but to a lesser degree, in Mazamastrongylus vietnamica (Dróżdż, 1965) and Mazamastrongylus janseni (Dróżdż, 1965) (see characters in Dróżdż, 1965; Jansen, 1986). Distally, the spicules of species referred to Mazamastrongylus by Jansen (1986) all lack the trabeculate, balloon, or fanlike membranes considered typical of Spiculopteragia (in part see Travassos, 1937; Skrjabin et al., 1954; Dróżdż, 1965; Hinaidy and Prosl, 1981). In accordance with Jansen (1986) these 7 species, pending further study, should constitute the genus Mazamastrongylus.

Indeed, this general concept for Mazamastrongylus largely parallels that developed for Skrjabinagia Kasimov, 1942 by Altaev (1953) who included M. dagestanica, Mazamastrongylus popovi, M. odocoilei, and others in this genus based on a clear distinction from Spiculopteragia. Although this concept for Skrjabinagia was shown to be artificial (Andreeva, 1956), species grouped on the basis of bursal morphology and spicule structure were later referred to Mazamastrongylus (see Jansen, 1986).

Absence of a spoon-shaped dorsal process in the spicules and differences in the synlophe in specimens of Sarwaria bubalis (Sarwar, 1956), indicate that the genus Sarwaria is distinct from Mazamastrongylus (see Gibbons and Khalil, 1982; Jansen, 1986, 1989; Dróżdż, 1995; Lichtenfels et al., 1996). Further, definable differences in the synlophe, bursa, and accessory bursal membrane (see Dróżdż, 1995; Lichtenfels et al., 1996) refute the synonymy of Sawaria with Spiculopteragia as presented by Durette-Desset $(1982,1983,1989)$.

In contrast to Jansen (1986), the species composition for $\mathrm{Ma}$ zamastrongylus advocated by Dróżdż (1995) would exclude $M$. vietnamica and $M$. janseni and refer them to the genus Spiculopteragia as major and minor morphotypes constituting a single polymorphic species; 5 species would be retained in Mazamastrongylus. Although this decision requires confirmation, it is apparent that generally polymorphism in males is not observed among species in the genus Mazamastrongylus (see Dróżdż, 1995). Further analysis will be required to determine if the structure of the dorsal process in conjunction with bursal attributes may serve as phylogenetic characters useful in recognizing Mazamastrongylus and Spiculopteragia.

Mazamastrongylus peruvianus and $M$. trinitatis are the only members of the genus endemic to the Neotropics (Cameron 1935, 1936; Guerrero and Chávez, 1967; Jansen, 1986). Overall, species appear to be limited to cervid hosts in the Nearctic $(M$. odocoilei and $M$. pursglovei in $O$. virginianus), the Palearctic ( $M$. dagestanica in Alces alces (Linnaeus) and Capreolus capreolus (Linnaeus)) and southeast Asia (M. vietnamica and $M$. janseni in Muntiacus muntjak (Zimmermann)). Records of $M$. dagestanica and 1 of its synonyms, Skrjabinagia popovi, from Ovis aries Linnaeus are unlikely to reflect the true host range in cervids (Dróżdż, 1965, 1967).

The distribution of M. peruvianus in South American camelids and M. trinitatis in Mazama americana may parallel the situation for Nematodirus lamae Becklund, 1963 and Nematodirus urichi Cameron, 1935 where colonization and subsequent speciation appear to have determined contemporary hostparasite relationships (see Hoberg et al., 1989; Rickard and Hoberg, 1990). The apparent morphological distinctiveness of species of Nematodirus Ransom, 1907 from cervids in the Western Hemisphere, suggests that camelids were colonized from a cervid source (see Hoberg at al. 1989; Rickard and Hoberg, 1990). The distribution of $M$. trinitatis in $M$. americana, $M$. pursglovei and $M$. odocoilei in $O$. virginianus, and $M$. peruvianus in camelids suggests derivation of the latter species via colo- 
nization. This is further supported by the absence of species of Mazamastrongylus in either Camelus bactrianus Linnaeus or Camelus dromedarius Linnaeus in Eurasia (Jansen, 1986).

These observations in part provide corroboration for the hypothesis for relationship of Mazamastrongylus and Spiculopteragia in Cervidae (Dróżdż, 1965, 1967, 1995). Recent studies of species of Spiculopteragia indicate that the historical distribution of this genus was limited to the Palearctic and only recently has it become widespread via faunal introductions (summarized in Rickard et al., 1993). In contrast, if the current species composition of Mazamastrongylus remains stable, this would indicate a broad distribution in the Holarctic, extending into the Neotropics (Jansen, 1986). This would be consistent with the divergence of Spiculopteragia and Mazamastrongylus coinciding with the diversification of cervids in Eurasia in the late Tertiary, followed by dispersal initially into the Nearctic and secondarily to the Neotropics as advocated by Dróżdż (1967, 1995). The putative coevolutionary history for these genera and other ostertagiines must be assessed within a phylogenetic context for hosts and parasites (Dróżdż, 1967; Hoberg and Lichtenfels, 1994) as a component of studies currently in progress.

\section{ACKNOWLEDGMENTS}

Arthur Abrams of the BNPCU assisted in morphometric studies, and in preparation of the synlophe figures. Patricia Pilitt of the BNPCU prepared transverse sections. Alexander Khrustalev of the K. I. Skrjabin Institute of Helminthology, Moscow, Russia assisted in elucidating some aspects of spicule morphology.

\section{LITERATURE CITED}

Altaev, A. KH. 1953. Two new trichostrongylids from Dagestan sheep Contributions to Helminthology published to commemorate the 75 th birthday of K. I. Skrjabin. Izdatel'stvo Akademiia Nauk, SSSR, Moskva. [English translation by Israel Program for Scientific Translations, Jerusalem, 1966, p. 15-22.]

ANDREEVA, N. K. 1956. Revizia roda Skrjabinagia (trichostrongilid) zhvachnikh. Trudy Instituta Veterinarii 8: 488-497.

Cameron, T. W. M. 1935. Studies on the endoparasitic fauna of Trinidad mammals. 1. Some parasites of Trinidad deer. Canadian Journal of Research 13: 89-96.

- 1936. Studies on the endoparasitic fauna of Trinidad mammals. Further parasites from Trinidad deer. Canadian Journal of Research 14: 165-167.

Chabaud, A. G., F. Puylaert, O. Bain, A. J. Petter, and M.-Cl. DURETTE-DESSET. 1970. Remarques sur l'homologie entre les papilles cloacales des Rhabdites et les côtes dorsales des Strongylida. Comptes Rendus Hebdomadaire des Séances de l'Academie des Sciences, Paris 271: 1771-1774.

DRóżdż, J. 1965. Studies on the helminths and helminthiases in Cervidae I. Revision of the subfamily Ostertagiinae Sarwar, 1956 and an attempt to explain the phylogenesis of its representatives. Acta Parasitologica Polonica 13: 445-481.

- 1967. Studies on the helminths and helminthiases in Cervidae III. Historical formation of helminthofauna in Cervidae. Acta Parasitologica Polonica 14: 287-300.

- 1995. Polymorphism in the Ostertagiinae Lopez-Neyra, 1947 and comments on the systematics of these nematodes. Systematic Parasitology 32: 91-99.

Durette-Desset, M. C. 1982. Sur les divisions génériques des Nématodes Ostertagiinae. Annales de Parasitologie Humaine et Comparée 57: 375-381.

. 1983. Keys to the genera of the superfamily Trichostrongyloidea, Vol. 10. In CIH keys to the nematode parasites of verte- brates, R. C. Anderson and A. G. Chabaud (eds.). Commonwealth Agricultural Bureaux, Farnham Royal, United Kingdom, 86 p.

. 1985. Trichostrongyloid nematodes and their vertebrate hosts: Reconstruction of the phylogeny of a parasitic group. Advances in Parasitology 24: 239-306.

- 1989. Nomenclature proposée pour les espèces décrites dans la sous-famille des Ostertagiinae Lopez-Neyra, 1947. Annales de Parasitologie Humaine et Comparée 64: 356-373.

Gibbons, L. M., AND L. F. Khalil. 1982. A key for the identification of genera of the nematode family Trichostrongylidae Leiper, 1912. Journal of Helminthology 56: 185-233.

Guerrero, C. A., AND C. A. ChÁvez. 1967. Helmintos comunicados proprimera vez en alpacas (Lama pacos), con una descripción de Spiculopteragia peruvianus n. sp. Boletin Chileno de Parasitologia 22: 147-150.

Hinaidy, H. K., AND H. Prost. 1981. Proposals to the systematics of Ostertagia species: Tribe Spiculopteragiini. Parasitology 82: 181183.

Hoberg, E. P., Fruetel, M., AND L. G. Rickard. 1989. Synlophe of Nematodirus odocoilei (Trichostrongyloidea) from deer and caribou in North America with comments on the evolution of Nematodirus spp. among the Cervidae (Artiodactyla). Canadian Journal of Zoology 67: 1489-1494.

- AND J. R. LICHTENFELS. 1994. Phylogenetic systematic analysis of the Trichostrongylidae (Nematoda), with an initial assessment of coevolution and biogeography. Journal of Parasitology 80: 976996.

, - AND P. A. PILITT. 1993a. Comparative morphology of Ostertagia mossi and Ostertagia dikmansi (Trichostrongylidae) from Odocoileus virginianus and comments on other Ostertagia spp. from the Cervidae. Systematic Parasitology 24: 111-127.

, - AND 1993b. Synlophe of Cooperia neitzi (Trichostrongylidae: Cooperiinae) with comments on vulval inflations and hypertrophy of cuticular ridges among the trichostrongylids. Journal of the Helminthological Society of Washington 60: 153161.

JANSEN, J. 1981. Spiculopteragia (Orloff, 1933) and related genera. Parasitology 82: 183-184.

- 1986. Redescription of Mazamastrongylus trinitatis Cameron, 1935 and a discussion on the systematic position and species composition of the genus Mazamastrongylus Cameron, 1935 (Nematoda: Trichostrongyloidea). Systematic Parasitology 8: 279-283.

- 1989. A concise history of the Ostertagiinae Lopez-Neyra, 1947 (Nematoda: Trichostrongyloidea) and a discussion on its composition. Acta Leidensia 58: 151-159.

LANCASTER, M. B., AND C. HoNG. 1990. The identification of females within the subfamily Ostertagiinae Lopez-Neyra 1947. Veterinary Parasitology 35: 21-27.

Lichtenfels, J. R., AND E. P. Hoberg. 1993. The systematics of nematodes that cause ostertagiasis in domestic and wild ruminants in North America: An update and key to species. Second Ostertagia Workshop, University of Maryland. Veterinary Parasitology 46: 33-53.

, - P. A. Pilitt, AND A. M. G. Belem. 1993. A comparison of cuticular ridge patterns and other morphological characters of Mazamastrongylus odocoilei and Mazamastrongylus pursglovei (Nematoda: Trichostrongyloidea) from white-tailed deer Odocoileus virginianus. Systematic Parasitology 24: 1-15.

$\longrightarrow,-\longrightarrow$, AND T. M. Craig. 1996. The synlophe and other structural characteristics of Sarwaria bubalis (Nematoda: Trichostrongyloidea) from cattle in Guyana. Journal of Parasitology 82: 146-154.

, AND P. A. Pilitt. 1991. A redescription of Ostertagia bisonis (Nematoda: Trichostrongyloidea) and a key to species of Ostertagiinae with a tapering lateral synlophe from domestic ruminants in North America. Journal of the Helminthological Society of Washington 58: $231-244$.

RICKARD, L. G., AND E. P. Hoberg. 1990. Evaluation of the synlophe of Nematodirus urichi and $N$. lamae (Trichostrongyloidea) from Mazama americana and camelids (Artiodactyla) in the Neotropics. Canadian Journal of Zoology 68: 1005-1011.

, N. M. Allen, G. L. Zimmerman, and T. M. Craig. 1993. Spiculopteragia spiculoptera and $S$. asymmetrica (Nema- 
toda: Trichostrongylidae) from red deer (Cervus elaphus) in Texas. Journal of Wildlife Diseases 29: 512-515.

SARWAR, M. M. 1957. Observations on the morphology of Spiculopteragia asymetrica (Ware, 1925) and a discussion on its relationship. Zeitschrift für Parasitenkunde 18: 1-4.

Skrjabin, K. I., N. P. ShIKhObalova, and R. S. Shul'ts. 1954. Es- sentials of nematodology III. Trichostrongyloids of animals and man. Academy of Sciences USSR, Moscow. [English translation by Israel Program for Scientific Translations, Jerusalem, 1960, 704 p.] Travassos, L. 1937. Revisão da familia Trichostrongylidae Leiper, 1912. Monografias do Instituto Oswaldo Cruz 1: 1-512. 